\title{
Poverty, Inequality and Underdevelopment in Third World Countries: Bad State Policies or Bad Global Rules?
}

\author{
Ashaver, Benjamin Teryima \\ Department Of Political Science Benue State University, Makurdi - Nigeria
}

\begin{abstract}
This paper examines the twin issues of poverty and inequality as well as the underdevelopment of Third World Countries to see if the above have been caused by bad state polices of these countries or bad state global rules using the Neo-Marxist or Dependency School, the paper discovers that even though many developing countries have good state policies, their implementation has been hindered by bad global rules which are weighed against Third World Countries, especially Africa. This has hindered development in these counties. It is an established fact that development cannot take place where there is mass poverty and inequality. Drawing examples from some Third World Countries, it is clear that global rules are not in favour of the Third World. It is the position of this paper that if Third World Country must develop they must extricate themselves from the intricacies of global rules through the globalization process.
\end{abstract}

\section{Introduction}

There is no doubting the fact that Third World Countries are naturally endowed in both material and human resources. It is rather pathetic that some of these countries are so underdeveloped despite this natural advantage. The plundering of the resources of these countries during colonialism has largely been responsible for this present situation. Even though some of the counties in the Third World have found their path to development, others, mainly in Africa, have not. One question comes to mind. Is it bad global rules that are responsible for this or bad state policies of these Third World Counties? According to Saul (2006:2):

The rest of the world was subordinated to the economic requirements of expanding European economic and military might. As a result, by the $19^{\text {th }}$ and $20^{\text {th }}$ centuries, most of the global south had been battered and pillaged, and then ultimately tied to Western economic centres by lead-strings of economic and political (including formally colonial)provenance. A global hierarchy was then formed, in geographical, class and racial terms that would have a profound, even crippling effect of the economic and social prospects of the vast majority of the world's population.

This is the situation in the world today. The West, led by the USA, dictates to the rest of the world, especially the third world, how their economies are to be run. This is done through stringent global rules of the IMF and World Bank. Therefore state policies of the third world countries cannot survive as their implementations are tied to the letters of these global rules.

To effectively handle the above, the work has been broken down as follows: Following the introduction is conceptual clarifications where the concepts of poverty, inequality, third world counties and underdevelopment are explained. The dependency theory is used as the framework of analysis. Then follows the examination of global rules and state policies as they relate to underdevelopment of the third world. Finally, the way forward is suggested and then the conclusion.

\section{Conceptual Clarifications}

The terms of poverty, inequality, third world countries and underdevelopment need proper conceptualization in this paper:

i. Poverty

As a multi-dimensional phenomenon, poverty has no universal accepted definition. However, Aluko (1975) views poverty as "a lack of command over basic consumption needs", which means that there is an inadequate level of consumption giving rise to insufficient food, clothing or shelter, and moreover, the lack of certain capacities such as being able to participate with dignity in society.

Quoting Alimeka in Ndelifera, (2007), Genyi (2007:10) agrees that:

Poverty has various manifestations including lack of income and productivity resources sufficient to ensure sustainable livelihoods, hunger and malnutrition, ill-health, limited or lack of access to education and other basic services, increase morbidity from illness, homelessness and inadequate housing, unsafe environment. Social discrimination and exclusion. It is also characterized by a lack of participation in decision and in civil, social and cultural life. 
There is relative and absolute poverty. Onoja (2007:11) sees absolute poverty as a situation where levels of income are insufficient to provide the basic necessities of life, while relative poverty is a situation where an individual or region appears to have more than others in absolute poverty, yet has less than others in terms of income, property and other resources. The first criterion would include those people near the borderline of starvation or death from exposure, while the second criterion would extend to people whose nutrition, housing and clothing though adequate to pressure life, do not measure up to those of the population as a whole. Arguing in line with the above position, Ndelifu (2007: 12) contends that absolute poverty is characterized by low carolie intake, poor housing, inadequate health facilities, poor quality of educational facilities, low life expectation, high infant mortality, low income, unemployment and underdevelopment. Absolute poverty therefore refers to people who live below the poverty line of surviving on less than one dollar a day; they are unable to meet their basic needs.

The above position clearly shows that poverty is a state of deprivation or denial of the basic choices and opportunities needed to enjoy a decent way of living; to live a long healthy constructive life and to participate in the cultural life of the community.

\section{ii. Inequality}

Inequality in this context refers to an unequal distribution of benefits and losses under the uneven process of a globalized world. This is not to say that inequality does not exist within states. In fact, that is where it starts. This imbalance leads to polarization between the few countries and groups that gain, and the many countries and groups in society that loose out or are marginalized. Globalization, polarization, wealth concentration and marginalization are therefore linked through the same process (Khor, 2003: 9). It is of note that in the said process, investment resources, growth and modern technology are directed to a few countries (mainly in North America, Europe, Japan and East Asian Newly industrializing countries). Pathetically, majority of developing countries are excluded from the process, or are participating in it in marginal ways that are often detrimental to their interests.

Inequality is also manifested in the fast-growing gap between the world's rich and poor people and between the developed and developing countries, and in the large differences among nations in the distribution of gains and losses. Khor (2003:10), quoting the United Nations Development Programmes (UNDP) Human Development Report, 1992, further states that:

...20 percent of the world's population in the developed counties receives 82.7 percent of total world income, while the 20 percent of people in the poorest countries receive only 1.4 percent. ...in 1989, the average income of the 20 percent of people living in the richest counties was 60 times higher than that of the 20 percent living in the poorest countries. The ratio had doubled from 30 times in 1950... Since the early 1980s the world economy had been characterized by rising inequality, and North-South income gaps have continued to widen.

The implications of the increased inequality on the global are that: in the first place, there is increased concentration of national income in few hands which does not give room for faster growth and higher investment. Secondly, the fast pace of financial liberalization has delinked finance from international trade and investment. Higher interest rates due to restrictive monetary policies have raised investment costs entrepreneurs resort to buying and selling second-hand assets.

\section{iii. Third World Countries}

These are also referred to as countries of the Southern hemisphere or developing countries. Included here are countries from the continents of Africa, Asia and Latin America. According to Dirk and Nobert (2003:3):

Third World Countries are countries at the 'periphery' of the world economy and produce mainly agrarian and mineral raw materials for industrialized states under mostly negative terms of trade. Furthermore, as a result of high population growth and rural-urban migration, many of these countries have increasing number of marginalized sections of the population which have specific settlement patterns and living conditions.

According to Worseley (1987: viii):

The modes of first, second and third worlds are concepts that were first forged in the 1950s and now need rethinking as such categories are not immutable. Their value lies, rather, in their heuristic capacity to help us make sense of what is happening in the world.

However, at a point in time there was growing rapprochement between the industrialized superpowers, the one capitalist, the other communist (the USA and then USSR), which changed the relationship between the First and Second Worlds. There was therefore in existence, a plurality of communisms, exemplified in the Soviet black in the form of 'polycentric' tendencies of various East European countries to assert their own identities, despite successive repressions in Eastern Europe. But it is important to note that none of the models 
of three 'world' is definitive or entirely satisfactory, for they seek to capture a reality that contains at least two major dichotomies: developed and underdeveloped, on the one hand and capitalist and communist on the other. According to the Chinese (Peking Review No. 44, 1974):

The First World is that of the superpowers; the Second that of the developed countries; and the Third, the underdeveloped countries.

\section{iv. Underdevelopment}

Underdevelopment is not the absence of development, because every people have developed in one way or another and to a greater or lesser extent. Underdevelopment only makes sense as a means of comparing levels of development. It is very much tied to the fact that human social development has been uneven and from a strictly economic view-point some human groups have advanced further by producing more and becoming more wealthy (Rodney 1972:21). Our main pre-occupation this time around is with the disparity in wealth between Europe and North America on the one hand and Africa, Asia and Latin America on the other. In comparism with the first, the second group can be said to be backward or underdeveloped. The idea behind underdevelopment is therefore a comparative one.

Underdevelopment can also be explained in terms of relationship of exploitation of one country by another. All the countries classified as underdeveloped in the world were exploited by others. The underdevelopment with which the world is now preoccupied is a product of capitalist, imperialist and colonialist exploitation. Rodney (1972:22) therefore concludes that:

If underdevelopment were related to anything other than comparing economies, then the most underdeveloped country in the world would be the USA, which practices external oppression on a massive scale, while internally there is a blend of exploitation, brutality and psychiatric disorder.

\section{Theoretical Framework}

The dependency school would be used as the theoretical framework of analysis. The concept of dependency was first used by Latin American writers seeking to account for the fact that, in spite of having won formal independence from Spain or Portugal before the middle of the $19^{\text {th }}$ century, a hundred years later, their countries had mostly failed to develop into modern, industrialized societies. In the $1950 \mathrm{~s}$ it became the basis of influential analyses of development by scholars such as Furtado, Dos Santos, and Fernando Cardoso.

Other terms used to bear the same meaning with dependency include, semi-colonialism which Lenin used in 1916 with reference to Latin America. Nkrumah, and Fanon called it Neo-colonialism, referring to post independence Africa in the 1960s while Gunder Frank, studying the Latin American experience from the early $19^{\text {th }} \mathrm{c}$ to the 1960 s called it "Underdevelopment".

According to Frank, his dependency or underdevelopment thesis holds that the development of the west was possible through the subordination and exploitation of the former colonies at the expense of the periphery's stagnation and impoverishment which has continued to be so. According to Frank, real economic development at the periphery only occurred during world wars one and two or during the depression of the 1930s when trade and investment links between the metropole and the periphery were broken or weakened. The solution to the problem of underdevelopment was therefore to end the condition of dependency through a revolutionary break. This has also been referred to as "delinking", or "new international economic order".

The relevance of the concept of dependency lies in the analysis in produced of the impact of imperialism, past and present, on the former colonies. Their economic structures tend to reflect the original reason for making them colonies: the production of primary commodities for export, and the creation of an infrastructure of railways, roads, ports and telecommunications oriented to exports, not the promotion of an integrated national economy offering viable internal markets for more than basic goods. In the most extreme cases, the whole economy may be based on the export of just one or two commodities and be vulnerable to world market fluctuation or bad weather.

\section{Global Rules And State Policies As Facilitators Of Poverty, Inequality And Underdevelopment In The Third World}

That a new world economic, political and cultural order has emerged is no longer news. This has been characterized by liberalization and intensification of international linkages in trade, finance, markets, politics and culture accelerated by micro electronics and information technology. This is otherwise known as globalization. There is therefore the accelerated integration of capital, production and markets globally, a process driven by the logic of corporate profitability. The origin of global rules predate the colonial period. Over five centuries ago, firms in the economically advanced countries have increasingly extended their outreach through trade and production activities, (which were intensified in the colonial period), to territories all over the world. However, in the past two to three decades, this process has been accelerated as a result of technological development and especially the policies of liberalization that have swept across the world (Khor, 2003:1). 
An examination of global rules shows that they do not favour Third World Countries at all. Rather than enhance development, the Third World is perpetually enslaved by the capitalist west. Global rules and domestic policies tend to enhance poverty in third world countries. The USA, through the "new international financial architecture" has imposed on the rest of world her own rules that determine how local policies of developing countries are to be formulated and implemented. Contrary to USA claims this new architecture is not at all development friendly. Rather, it is project of consolidation of inequality between nations and between classes within nations (Soederberg, 2004:180). According to Saul (2006:11):

The well known decline in the terms of trade for developing countries is closely related to unbalanced nature of their economies, as a result of which so many of them consume what they do not produce, and produced what they do not consume. However, the decline in the terms of trade contributed significantly to growing indebtedness, which eventually obliged so many countries to accept the "structural adjustment" programmes imposed as a condition of further aid by the IMF and the World Bank.

Not only was structural adjustment a new form of dependency, it also tended to reinforce many of the features of these countries' economies - especially their reliance on a few commodity experts - which were at the root of their economic difficulties.

Another issue is how to treat foreign aid. The IMF and World Bank do not like quick repayment of loans. They rather prefer a situation whereby Third World Countries continuously serve these loans from time to time for continued dependence on them. An example of the dispute between IMF and Ethiopia over early repayment of loan readily comes to mind. According to Stiglitz (2002:30):

Ethiopia had repaid an American Bank loan early, using some of its reserves. The transaction made perfect economic sense. In spite of the quality of the collateral (an airplane), Ethiopia was paying a far higher interest rate on its loan than it was receiving on its reserves. The USA and the IMF objected to the early repayment. They objected not to the logic of the strategy, but to the fact that Ethiopia had undertaken this course without IMF approval.

If one may ask, why should a sovereign country take permission from IMF for every action which it undertakes? One might have understood if Ethiopia's action threatened its ability to repay what was owed the IMF; but quite the contrary, because it was a sensible financial decision, it enhanced the country's ability to repay what was due.

Another issue is that of spreading of ideological doctrine of liberal democracy. According to Okpaga (2003:63):

This entails the transformation of institutions, groups and the universalization of certain practices, identities and structures that are likened to those of the advanced world. It will, in essence, entail that a state that does not practice these liberal democratic values can therefore be said to be underdemocratic.

This situation is worrisome because, liberal democracy based on the value system of the West does not seem to be working well in the third world. This is due to lack of integration with the local cultural values of these counties. According to Sorkaa (3003:31):

A more democratic system of government should be developed. This is a democratic system of governance that involves more than Western liberal democracy that lays emphasis on multiparty democracy and an electoral process of voting once in a while for the leadership to run the affairs of government. In Nigeria, people usually vote without choosing their leaders. It is rather unfortunate that the political class that took over the reigns of political power independence in 1960 have never had any interest in transforming the colonial state from a coercive force to an instrument of national development in the interest of all.

Financial liberalization is another way of retaining structural power by the west at the expense of the

Third World Countries. According to Soederberg (2004:1):

The US remains wedded to financial liberalization because it is in the interests of transactional corporations and the American government itself to retain their structural power in the global economy. The US is using its political and economic muscles to compel the rest of the world, and notably the emerging markets in the South and elsewhere, to expose their economies to the unregulated demands of international (mainly Western) finance.

But it is a known fact that this tinkering with the capitalist system will not achieve either sustained economic growth or stability in financial markets, let alone enhance the capability of developing countries to tackle the problems of mass poverty and social injustice.

The case of the East Asian countries will suffice here. When the THAI BAHT collapsed in 1997, it was least expected that it would result to crisis that would spread from Asia to Russia and Latin America and threaten the entire world. For ten years, the BAHT had traded at around 25 to the dollar; then overnight it fell by 25 percent. Currency speculation spread and hit Malaysia, Korea, the Philippines and Indonesia. What started as an exchange rate disaster took down many of the region's banks, stock markets and even entire economies. The effects of the crisis are still being felt in the region especially in Indonesia. According to Stiglitz (2002:89): 
The IMF policies imposed during this tumultuous time worsened the situation. Indeed, it becomes clear that the IMF policies not only exacerbated the downturns but were partially responsible for the excessively rapid financial and capital market liberalization. This was probably the single most important causes of the crisis, though mistaken policies on the part of the countries themselves played a role as well.

Trade liberalization, just like financial liberalization, is another way of sustaining poverty, inequality and underdevelopment in the third world. The argument is that trade liberation is necessary and has automatic and generally positive effects for development. This is being challenged empirically and analytically. According to Khor (2003:22):

The nation that all gainers and there are no losers in trade liberalization has proven to be over simplistic. Some countries have gained more than others; and many (especially the poorest countries have not gained at all but have suffered severe loss to their economic standing. With the notable exception of China, liberalization has resulted in a general widening of the gap between the annual growth of imports and exports in Latin America, where the gap average 4 percentage points.

From the above, one can rightly say that if trade liberalization is carried out in an inappropriate manner in countries that are not ready or able to cope or which face conditions that are unfavourable, it can contribute to a vicious cycle of trade and balance-of-payments deficits, financial instability, debt and recession.

Investment liberalization is another way of controlling the economies of third world countries. The main elements here include the right of entry and establishment of foreign investors and investments; the right to full equity ownership; national treatment (treating foreign investors like their local counterparts), the right to free transfer of funds and full profit repatriation; protection of property from expropriation etc. In the 1970s, governments of developing countries were skeptical of foreign investments. As from the 1980s however, foreign investment were viewed more positively. That as a form of foreign capital, investments are superior to loans because investments (unlike loans) would not land the host country into a debt crisis. That foreign investment is being seen as a panacea for removing the obstacles to development. In actual fact however, there are benefits and costs to foreign investment.

Contributing on the effects of Foreign Direct Investment (FDI) on savings, financial inflows and outflows, trade and growth, Ghazali (1996) quoted by Khor (2003:73) concludes that:

Successful growth in developing countries is premised essentially on raising the domestic saving rate to a high level and productively investing the saving. This is more important than the role of foreign capital, including FDI. The East Asian growth success is based mainly on high domestic savings rather than FDI. Foreign capital can help to supplement domestic savings but this has its downside... FDI has a negative effect on domestic savings, as it gives room for the recipient country to increase its consumption.

However, Ghazali proposes that for FDI to be useful, with net overall benefit, the following conditions are necessary: availability of foreign capital does not detract from own saving effort; the factor payment cost must be minimized and prudently managed... To avoid reliance of foreign on foreign capital, development countries should increase their savings rate and maintain sound economic and political conditions.

Since there are various categories of foreign investment, it is important for third world countries to distinguish between the different types, understand the characteristics and effects of each type, and formulate policies to deal with each.

Another important issue worth mentioning is structural adjustment programmes. It is necessary for countries to restructure their economies from time to time. However, the IMF and World Bank induced structural adjustments, with their stringent conditionalities of devaluation of currency, removal of subsidies, retrenchment of the workforce, privatization and commercialization etc., are not in the best interest of third world countries. For example, the structural adjustment programme introduced in Nigeria in the mid 1980s, by the Babangida administration was IMF and World Bank induced with the harsh conditionalities earlier mentioned. This was despite the rejection of SAP by the political bureau which that regime had established. This sparked off crises all over the country. In response, government introduced policies to cushion the effects of SAP. These measures did not take Nigeria out of the problems created by the restructuring of the economy. The hardships Nigerians are now facing are as a result of the effects of SAP.

\section{The Way Forward}

There is no doubt that poverty, inequality and underdevelopment characterize the continents of Africa, Asia and Latin America, while some of the countries in Asia and Latin America have made some efforts at industrialization, the African continent still lags behind. This is as a result of the twin problems of unfavourable global rules and policies of these countries which they cannot implement favourably. As peripheral states, they lack the political will to challenge the existing world situation where the West, especially the USA dictates how their economies are to be run. 
taken:

If third world countries are to develop and reduce poverty and inequality, the following steps should be

1. Developing countries should have more rights of participation in decision making processes in the IMF, World Bank and WTO, which should also be made more accountable to the public and to the local and poor communities. This will enhance appropriate and democratic global governance

2. Developing countries should, as a matter of necessity, review the liberalization experience and make important conclusion on the balance and mix between the roles of the state and the market.

3. Governance at the national level should combine economic development, environmental concern and social justice. In both North and South, the wide disparities in wealth and income within counties have to be narrowed. The situation of improved equity would enhance the planning and implementation strategies of economic adjustment to social and ecological goals.

4. Since global capitalism does not work for the poor, and since there is little or no alternative to it, third world should identify a viable global left with a viable global policy to counter capitalism and establish a global alternative with real growth potential with more egalitarian practice to it.

5. States should evolve policies that are development oriented. These should aim at reducing poverty and inequality. This is particularly in Africa, where there is no linkage between policy formation and policy implementation.

\section{Conclusion}

We have considered the issues of poverty, inequality and underdevelopment in Third World Countries and have discussed how unfavourable global rules and lack of proper implementation of state policies have been the major causes of problems. The globalizing world does not seem to favour Third World to Developing countries. The advanced North has continued to dominate the rest of the world; the South on the other hand, has been at the receiving end of inequalities. This situation is antithetical to development in the South. In the $21^{\text {st }}$ century, much more focus has to be placed on charging the political and economic behaviour of the world.

\section{Bibliography}

[1]. Bello, W. (2004) Deglobalization: Ideas for a New World Economy. The University Press

[2]. Dirk, B. S. and Norbert, K. (eds.) (2003) Poverty and Democracy: Self-help and Political Participation in Third World Cities. Zed Books Ltd. London.

[3]. Genyi, M. E. (2008) "Poverty, Good Governance and Development Process in Nigeria", Paper presented at the Abuja International Conference on Arts and Humanity between $3^{\text {rd }}-7^{\text {th }}$ November at the University of Abuja - Nigeria.

[4]. Khor, M. (2003) Globalization and the South: Some Critical Issues. Spectrum Books Ltd Ibadan.

[5]. Onoja, A. O. (2007) "Poverty Dimensions and Policies of Rural Poverty Reduction in Nigeria" in Okpe, O. et al (eds.) The MiddleBelt in the Shadow of Nigeria Makurdi. Oracle Business Ltd.

[6]. Saul, J. E. (2005) Development After Globalization: Theory and Practice for the Embattled South in a New Imperial Age Zed Books Ltd. London. 